\title{
Relationship factors physical environment and behavior house respondents with incidence of dengue hemorrhagic fever in Depok West Java, Indonesia 2016
}

\author{
Fathinah Ranggauni ${ }^{1^{*}}$, Nuning Maria Kiptiyah ${ }^{1}$ \\ Departemen Epidemiologi, Program Studi Epidemiologi, Fakultas Kesehatan Masyarakat \\ Universitas Indonesia
}

DOI: http://dx.doi.org/10.19106/JMedScieSup005001201802

\section{ABSTRACT}

Depok City is one of the endemic areas of dengue disease in Indonesia. An increase and spread of dengue cases was likely caused by the high mobility of the population, urban development, climate change, changes in population density, and distribution. This research was ananalytics tudy with case control design. This study found that in bivariate analysis, the variables associated with the incidence of dengue in the city of Depok were variable lighting $(\mathrm{OR}=2.857,95 \% \mathrm{Cl}=1.179$ to 7.175$)$, variable cleaning TPA (OR=2.210, $95 \% \mathrm{Cl}=0.972$ to 5.103$)$, and variable educational level $(\mathrm{OR}=24.37595 \% \mathrm{Cl}=3.540$ to 1030.606). On multivariate analysis, the home environment variables that individuals with home lighting in eligible risk of $3.369(95 \% \mathrm{Cl}=1.418$ to 8.005$)$ compared to individual sex posed to dengue home lighting qualify as controlled by confounding variables, namely the habit of cleaning water reservoirs and jobs. On multivariate analysis, behavioral variables respondent was an individual who cleans water reservoirs not routinely, $<1$ time a week, was at risk of 3.293(95\% Cl:1.321 to 8.212) DHF compared with in dividuals who have the habit of cleaning water reservoirs regularly after confounding variables are controlled by environmental conditions and education of home lighting. In Depok City Health Department inspection home lighting conditions and larvae regularly, fogging and improve health promotion to respondents on how to prevent dengue by conducting $3 \mathrm{M}$ plus especially on variable bath tub drain in order to suppress the incidence of dengue in the working area. Respondents suggested to joining and participating in efforts to mosquito nest eradication of dengue hemorrhagic fever (PSN-DBD).

Keywords: dengue, home physical environment - public behavior

*corresponding author: fathinahranggaunihardy@gmail.com 